\title{
Perioperative Management of a Pediatric Patient with Glanzmann's Thrombasthenia during Adenoidectomy
}

\author{
Erdem Nail Duman ${ }^{1}$, Sedat Saylan ${ }^{2}$, Bahanur Cekic ${ }^{3}$
}

Summary: Duman EN, Saylan S, Cekic B - Perioperative Management of a Pediatric Patient with Glanzmann's Thrombasthenia during Adenoidectomy.

Background and objective: Glanzmann's thrombasthenia (GT) is an autosomal recessively inherited platelet disorder. There is not any specific treatment. Platelet transfusion is currently the standard treatment when bleeding does not respond to local measures and/or antifibrinolytic treatment, although it may result in alloimmunization. Recombinant activated factor VII (rFVIla) might be used to avoid recurrent platelet transfusion.

Case report: We present early treatment with low-dose rFVIla additional to platelet transfusion in a 5-year-old pediatric case with diagnosis of GT who developed prolonged bleeding under an elective adenoidectomy surgery. A total dose of $1,200 \mu \mathrm{g}\left(60 \mu \mathrm{g} . \mathrm{kg}^{-1}\right) \mathrm{rFVIlla}$ could successfully stop bleeding, what can be accepted as low dose usage.

Conclusions: Such case reports may encourage the use of early treatment with low doses of rFVIla in severe bleeds that did not stop despite of platelet transfusion, as well as in preventing bleeding in surgical procedures in patients with GT. Actually, additional studies are needed to define the minimal effective dose and attempts to determine the lowest effective dose may be encouraged by the result of this case, considering financial restrictions in the health care system.

Keywords: Anesthesia, General; Adenoidectomy; Factor VIla/recombinant VIla; Thrombasthenia.

C2012 Elsevier Editora Ltda. All rights reserved.

\section{INTRODUCTION}

Glanzmann's thrombasthenia (GT) is an autosomal recessively inherited platelet disorder that is caused by deficiency or abnormality of the platelet membrane glycoprotein (GP) llb and/or IIla ${ }^{1}$. It is rare in a global context but relatively more common in populations where consanguineous marriages are frequent ${ }^{1}$. The disorder was first described in 1918 by the Swiss pediatrician Eduard Glanzmann in a group of patients with normal platelet count but impaired clot retraction and prolonged bleeding time ${ }^{1}$.

Clinical manifestations include spontaneous epistaxis, gum bleeding, easy bruising, purpura, menorrhagia, gastrointestinal bleeding, hematuria, muscle hematoma, and traumatic or postoperative bleeding with a normal platelet count ${ }^{1,2}$. There is not specific treatment. When bleeding does not respond to

Received from Department of Anesthesiology, Faculty of Medicine, Karadeniz Technical University, Turkey.

1. MD, Associate Professor, Karadeniz Technical University, Faculty of Medicine, Department of Anesthesiology, Turkey

2. MD, Anesthesiologist of the State Hospital, Turkey

3. MD, Assistant Professor, Karadeniz Technical University, Faculty of Medicine, Department of Anesthesiology, Turkey

Submitted on August 15, 2011.

Approved on December 15, 2011.

Correspondence to:

Erdem N. Duman, MD, Assoc. Prof.

Karadeniz Technical University

Faculty of Medicine, Department of Anesthesiology

TR-61080 Trabzon/Turkey

E-mail:dumanen@gmail.com local measures and/or antifibrinolytic drugs, platelet transfusion is currently the standard treatment. However, development of platelet refractoriness due to alloimmunization to GP IIb-IIla and/or HLA may occur as a common problem after repeated platelet transfusions ${ }^{2}$. Blood products also carry other risks, including infections ${ }^{2}$. Recombinant activated factor VII (rFVIla) might be used to avoid recurrent platelet transfusion, thereby reducing exposure to the associated risks, and to stop bleeding unresponsive to repeated platelet transfusion ${ }^{1,3,4}$. In a large international survey, rFVIla treatment was found to be effective in $94 \%$ of evaluable surgical procedures and in $75 \%$ of evaluable bleeding episodes ${ }^{2}$. It is also recommended that treatment should be administered as early as possible: in the report of Almeida et al. ${ }^{5}$ good or excellent responses were observed in $71 \%$ of bleeds treated within 12 hours of onset, but in only $18 \%$ of bleeds treated after 12 hours.

We present an early low-dose rFVIla use in addition to platelet transfusion in a pediatric case with GT who developed prolonged bleeding under an elective adenoidectomy surgery.

\section{CASE REPORT}

A 5 year-old boy of consanguineous parents with the diagnosis of GT was referred to "Ear, Nose and Throat Surgery Department" of our hospital with complaints of snoring, recurrent tonsillopharyngitis, sleeping apnea episodes and mouth breathing at sleeping, and because of these complaints tonsils and adenoids surgery was planned. The patient was diagnosed with GT two years ago, subsequent to the develop- 
ment of nose bleedings and bruisings. On the first admission, laboratory tests revealed that normal PT $(16.3 \mathrm{sec})$ and APTT $(29.2 \mathrm{sec})$ and INR: 1.31 . He had a prolonged bleeding time over 15 minutes, and normal platelet count $\left(270 \times 10^{9} . \mathrm{L}^{-1}\right)$. The diagnosis of GT was established by the absence of platelet aggregation in response to ADP, collagen, epinephrine and ristocetin.

Preoperative laboratory findings of the patient were as follows: a prolonged bleeding time ( $>15$ minutes) with a normal platelet count $\left(282 \times 10^{9} \cdot \mathrm{L}^{-1}\right)$, normal PT $(14.4 \mathrm{sec})$ and aPTT $(28.5 \mathrm{sec})$ levels and INR 1.15. His hemoglobin level was 9.9 g. dL-1. He was taking iron supplementation treatment for his anemia for the last five months. Because of a problem in flow-cytometry analysis, it could not be checked whether the patient had alloantibodies to platelet Gp Ilb/llla. He received platelet concentrate in a dose of $10 \mathrm{cc} . \mathrm{kg}^{-1} 30$ minutes before the surgery. Two 20G cannulae were placed in forearm veins. Induction of anesthesia was performed using thiopental, fentanyl and atracurium, followed by orotracheal intubation. Anesthesia was maintained with oxygen, nitrous oxide and sevoflurane. The bleeding of surgical site did not stop after adenoidectomy, so the tonsillectomy was abandoned. The bleeding could not be stopped within an hour with a platelet transfusion of $10 \mathrm{cc} . \mathrm{kg}^{-1}$ and red blood cell transfusion $7 \mathrm{~mL}$. $\mathrm{kg}^{-1}$, the blood loss reached to $270 \mathrm{cc}$, hemoglobin level was 8.8 g.dL-1, platelet count was $256 \times 10^{9} . \mathrm{L}^{-1}$, PT $14.2 \mathrm{sec}$, aPTT $28.1 \mathrm{sec}$. The option of applying tranexamic acid and fresh frozen plasma was not available at that time. Only an option of rFVIlla (Novo Nordisk A/S, Bagsvaerd, Denmark) in a total dose of $1,200 \mu \mathrm{g}\left(60 \mu \mathrm{g} . \mathrm{kg}^{-1}\right)$ was available; therefore, this treatment was administered in three minutes. Bleeding stopped in ten minutes after giving rFVlla; operation was ended and the patient was extubated. He was transferred to the post-anesthesia care unit and observed for three hours. His repeated blood counts were $8.4 \mathrm{~g}^{\mathrm{dL}}{ }^{-1}$ for hemoglobin and $292 \times 10^{9} . \mathrm{L}^{-1}$ for platelet count. Because of his anemia, red blood cell transfusion $\left(5 \mathrm{cc} . \mathrm{kg}^{-1}\right)$ was given. He was discharged on the third postoperative day from the hospital and had no further problems.

\section{DISCUSSION}

GT is a rare disorder and its clinical manifestations are similar to other platelet function disorders. Platelet transfusion is the standard treatment for severe bleeding and surgical support in these patients. However, repeated platelet transfusions can result in alloimmunization, which makes subsequent transfusions ineffective ${ }^{1}$. Hemostasis is started by the formation of a complex between tissue factor and activated factor VII following trauma or injury. It has been shown that $\mathrm{rFVIla}$ can induce hemostasis via binding to the surface of activated platelets to directly activate factors IX and $\mathrm{X}$ independent of tissue factor and thus enhance thrombin generation in the absence of FVIII and FIX.

In the literature, it has been demonstrated that rFVIla is an alternative treatment for bleeding and surgical support with less adverse effect ${ }^{1-4}$. The first reported use of $\mathrm{rFVIla}$ occurred in 1988 in a hemophilia patient. In a retrospective surgical case series reported by O'Connell et al. ${ }^{6}$, a wide range of $15-180 \mu \mathrm{g}_{\mathrm{kg}}{ }^{-1} \mathrm{rFVIla}$ is used for massive bleeding. In 1996, Tengborn and Petruson first reported the successful use of rFVIla for treating severe epistaxis in a 2-year-old boy with GT who had not responded to conservative treatment ${ }^{7}$. After this report, rFVIla was used by other investigators for bleeding episodes or surgery in patients with GT with or without alloantibodies to platelet Gp IIb/IIla complex or HLA ${ }^{1,3,4,8,9}$. We also used rFVIla for treating this pediatric GT patient under adenoidectomy surgery for the first time in the literature. In a large international survey, rFVIla treatment was found to be effective in $94 \%$ of evaluable surgical procedures and in $75 \%$ of evaluable bleeding episodes ${ }^{2}$. It is also recommended that treatment should be administered as early as possible: in the report of Almeida et al. ${ }^{5}$ good or excellent responses were observed in $71 \%$ of bleeds treated within 12 hours of onset, but in only $18 \%$ of bleeds treated after 12 hours.

The optimal dose and interval have not yet been determined for rFVIla use in GT patients. The reported treatment protocols are quite heterogeneous with respect to doses, duration and modalities of administration and associated treatments ${ }^{9}$. At present, the relationship between the doses of rFVIIa, the thrombin burst crucial for stable clot formation, and the actual measurable blood FVII levels are still unknown. Even though the minimum rFVIla level that is necessary to maintain hemostasis is unknown, the standard recommended dose is $90 \mu \mathrm{g} \cdot \mathrm{kg}^{-1}$ (range 80-120 $\mu \mathrm{g}$ ) at intervals of two hours (at least 3 doses) ${ }^{10}$. However, use of low doses such as $67 \mu \mathrm{g} . \mathrm{kg}^{-1}$ was reported in a review related with the intraoperative use of recombinant activated factor $\mathrm{VII}{ }^{11}$. In a report of $\mathrm{rFV}$ lla use in trauma patients, doses of $60-100 \mu \mathrm{g} / \mathrm{kg}$ were used ${ }^{12}$.

In a study done by Almeida et al. ${ }^{5}$, a single dose of $100 \mu \mathrm{g} \cdot \mathrm{kg}^{-1}$ was given in bleeding episodes of two children with GT, and because of an excellent response, they required no maintenance dose ${ }^{5}$. We also achieved to maintain the adequate homeostasis with early use of a single low-dose $\mathrm{rFVIla}$ such as $60 \mu \mathrm{g} \cdot \mathrm{kg}^{-1}$ additional to preoperative platelet transfusion in our GT patient. Use of $\mathrm{rFVIla}$ in a single dose of $70 \mu \mathrm{g} \cdot \mathrm{kg}^{-1}$ in the treatment of uncontrolled postsurgical hemorrhage in a patient with deep venous thrombosis was also found effective ${ }^{13}$. Moreover, in total hepatectomy case with a life threatening bleeding unresponsive to platelet transfusion, single bolus dose of $90 \mu \mathrm{g} \cdot \mathrm{kg}^{-1} \mathrm{rFVIlla}$ was successfully used ${ }^{14}$. Several analyses have suggested that early treatment with rFVIla is particularly beneficial, resulting in improved success rates with lower doses ${ }^{5,15}$.

As mentioned by Poon et al. ${ }^{4}$ many of the bleeding episodes did not bleed again in the absence of maintenance doses. It is possible that in patients with normal plasma coagulation systems, once a primary platelet plug has formed to stop bleeding, a permanent clot is readily formed by the fibrin deposition and stabilization. However, maintenance doses may be needed for severe, posttraumatic and gastrointestinal bleeding. 
In summary, although this unique case report is not enough to make a precise decision about the use of rFVIla in GT patients while bleeding and it is hard to perform randomized clinical trials in a rare condition like GT, such case reports may encourage the use of early treatment with low doses of rFVIla in severe bleeds that did not stop despite of platelet transfusion, and in preventing bleeding in surgical procedures in such patients. In addition, it may help to reduce exposure to the risks after repeated platelet infusions. Actually, additional studies are needed to define the minimal effective dose; therefore, attempts to determine the lowest effective dose of such an expensive compound may be encouraged by the result of this case in the presence of financial restrictions in the health care system. 
8. Uzunlar HI, Eroglu A, Senel AC et al. - A patient with Glanzmann's thrombasthenia for emergent abdominal surgery. Anesth Analg, 2004;99:1258-1260.

9. Coppola A, Tufano A, Cimino E et al. - Recombinant factor VIla in a patient with Glanzmann's thrombasthenia undergoing gynecological surgery: open issues in light of successful treatment. Thromb Haemost, 2004; 92:1450-1452.

10. Novo Nordisk. Disponível em: [http://www.novonordisk.com/therapy_areas/haemostasis/hcp/product_info/novoseven/treatment_areas/glanzmanns_thrombasthenia.asp] [Acessado em March 2011].

11. De Gasperi A. - Intraoperative use of recombinant activated factor VII (rFVIIa). Minerva Anestesiol, 2006;72(6):489-494.

12. Chiara O, Cimbanassi S, Brioschi PR et al. - Treatment of critical bleeding in trauma patients. Minerva Anestesiol, 2006;72(6):383-387.

13. Marson F, Farnia A, Callegher L et al. - Use of recombinant activated factor VII (rFVIla-NovoSeven) in the treatment of uncontrolled postsurgical hemorrhage in a patient with deep venous thrombosis and caval filter. A case report. Minerva Anestesiol, 2006;72(7-8):675-682.

14. Cozzi P, Chiumello D, Tubiolo D et al. - Total hepatectomy, recombinant activated factor VII and rescue liver transplantation. Minerva Anestesiol. 2010;76(7):550-553.

15. Lusher JM - Early treatment with recombinant factor VIla results in greater efficacy with less product. Eur J Haematol, 1998;63(Suppl):710.

\section{REFERENCES}

1. Nair S, Ghosh K, Kulkarni B et al. - Glanzmann's thrombasthenia: updated. Platelets, 2002;13:387-393.

2. Poon M-C, d'Oiron R, von Depka M et al. - Prophylactic and therapeutic recombinant factor VIla administration to patients with Glanzmann's thrombasthenia: results of an international survey. J Thromb Haemost, 2004;2:1096-1103.

3. Erduran E, Aksoy A, Zaman D - The use of recombinant FVIla in a patient with Glanzmann thrombasthenia with uncontrolled bleeding after tonsillectomy. Blood Coagul Fibrinolysis, 2009;20(3):215-217.

4. Poon M-C, Demers C, Jobin F et al. - Recombinant factor VIla is effective for bleeding and surgery in patients with Glanzmann thrombasthenia. Blood, 1999;94(11):3951-3953.

5. Almeida AM, Khair K, Hann I et al. The use of recombinant factor VIla in children with inherited platelet function disorders. $\mathrm{Br} \mathrm{J}$ Haematol, 2003;121(3):477-481.

6. O'Connell NM, Perry DJ, Hodgson AJ et al. - Recombinant FVIla in the management of uncontrolled hemorrhage. Transfusion, 2003;43(12):1711-1716.

7. Tengborn L, Petruson B. A patient with Glanzmann thrombasthenia and epistaxis successfully treated with recombinant factor VIla. Thromb Haemost, 1996;5(6): 981-982. 